\title{
Lung function in preteenaged Canadian school children: Comparison with two standard prediction equations and examination of the effect of weight
}

\author{
Judith A LeeCH mD, SheRYl BARTLetT PhD, Michael WalkeR MSc, MaRK RaIZenNe BSc \\ Air Quality Health Effects Research Section, Environmental Health Division, \\ Health Canada, Ottawa, Ontario
}

JA LEeCh, S BARTletT, M WALKer, M RAIZENNE. Lung function in preteenaged Canadian school children: Comparison with two standard prediction equations and examination of the effect of weight. Can Respir J 1996;3(4):241-246.

OBJECTIVES: To compare prediction curves for forced vital capacity (FVC) in children from a large population sample with the standard prediction curves currently in clinical use. A secondary objective was to assess the contribution of weight to the prediction of lung function in preteenagers.

DESIGN: The data used for this analysis were from a prospective cohort study of health effects of air pollution on children in 10 Canadian communities, five in Saskatchewan and five in Ontario.

PARTICIPANTS: A 96\% response rate among a target population of 4935 boys and girls aged seven to 11 years was attained. After exclusion of non-Caucasians and asthmatics there remained 3142 children.

ANALYSIS: FVC prediction curves for each sex were compared with the two standard prediction curves most frequently used in children's hospitals in Canada with respect to mean values and the lower limits of normal. A random subsample of 500 subjects was selected and their values were interpreted as normal or abnormal by the three prediction equations. Rates of abnormalcy between prediction methods were compared by the uncertainty coefficient statistic. Regression equations within each sex were examined for the effect of weight in addition to height.

MAIN RESULTS: Prediction curves from this large population sample were not statistically different from two widely used prediction curves in the mean or lower limits of normal in boys or girls. In 1575 boys a small but significant effect of weight was demonstrated ( $\mathrm{r}=0.024, \mathrm{P}=0.001)$ after age, height and square of height were added to the model (overall $\mathrm{r}^{2}=0.725$ ). Similarly, a significant effect of weight was seen in girls $\left(\mathrm{r}=0.022, \mathrm{P}=0.001\right.$, overall $\left.\mathrm{r}^{2}=0.756\right)$.

CONCLUSIONS: A large sample of nonsmoking Canadian children offers no further advantage in mean or lower limits of normal over standard predictions based on smaller convenience samples in generating prediction curves for normal FVC. In the youngest children who can perform pulmonary function tests, weight should be taken into account in epidemiological studies of pulmonary function. Although the effect may be small it is of the order of magnitude anticipated due to a number of different pneumotoxins (ie, air pollutants). (Pour le résumé, voir page 242.)

Key Words: Lung function prediction, Preteenagers

Correspondence and reprints: Dr JA Leech, Air Quality Health Effects Research, Room 203, Environmental Health Building, Tunney's Pasture, Ottawa, Ontario KlA OL2. Telephone 613-954-0161, fax 613-941-4546, e-mail Judy_Leech@isdtcp3.hwc.ca 


\section{Fonction pulmonaire chez des écoliers cana- diens préadolescents : Comparaison avec deux équations de prédiction standardisées et étude de l'effet du poids}

OBJECTIFS : Comparer les courbes de prédiction de la capacité vitale forcée (CVF) chez des enfants représentant un échantillon important de la population avec les courbes de prédiction standardisées, habituellement utilisées en milieu clinique. Un deuxième objectif était d'examiner la contribution du poids pour prédire la fonction pulmonaire chez les préadolescents.

MODÈLE : Les données utilisées pour la présente analyse ont été tirées d'une étude prospective de cohortes portant sur les effets de la pollution atmosphérique sur la santé, dans 10 communautés canadiennes dont, cinq en Saskatchewan et cinq en Ontario.

PARTICIPANTS : On a obtenu un taux de réponse de $96 \%$ parmi une population cible de 4935 garçons et filles âgés de 7 à 11 ans. Après avoir exclu les non caucasiens et les asthmatiques, il restait 3142 enfants.

ANALYSE : Les courbes de prédiction de la CVF pour chaque sexe ont été comparées avec les courbes de prédiction standardisées le plus fréquemment utilisées au Canada dans les hôpitaux pour enfants, par rapport aux valeurs moyennes et aux valeurs inférieures à la normale. Un sous-échantillon aléatoire de 500 sujets a été prélevé et les valeurs obtenues ont été interprétées comme normales ou anormales au moyen des trois équations de prédiction. Les taux d'anormalité entre les deux méthodes prédictives ont été comparés au moyen de la fonction du coefficient d'incertitude. Les équations de régression pour chaque sexe ont été étudiées relativement à l'effet du poids s'ajoutant à celui de la grandeur.

PRINCIPAUX RÉSULTATS : Les courbes de prédiction provenant de cet important échantillon de population n'étaient pas statistiquement différentes des deux courbes de prédiction couramment utilisées, dans les valeurs moyennes ou inférieures à la normale, chez les garçons ou les filles. Chez 1575 garçons, un effet minime mais significatif du poids a été démontré $(\mathrm{r}=0,024$, $\mathrm{P}=0,001$ ) après que l'on ait ajouté l'âge, la grandeur et le carré de la grandeur au modèle $\left(\mathrm{r}^{2}\right.$ global $\left.=0,725\right)$. De même, on a noté un effet significatif du poids chez les filles $\left(r=0,022, P=0,001, r^{2}\right.$ global $=0,756$ ).

CONCLUSIONS : Un important échantillon d'enfants canadiens non-fumeurs n'offre aucun avantage supplémentaire dans les valeurs moyennes ou inférieures à la normale sur les prédictions standardisées basées sur des échantillons plus petits et commodes pour générer des courbes de prédiction pour la CVF normale. Chez les enfants plus jeunes qui peuvent réaliser les épreuves de fonction pulmonaire, on doit tenir compte du poids dans les études épidémiologiques portant sur la fonction pulmonaire. Même si l'effet peut être minime, il est dans l'ordre de grandeur anticipée de l'effet d'un certain nombre de différentes pneumotoxines (par exemple, les polluants contenus dans l'air).
A s part of an investigation into the health effects of air pollution in 10 rural communities, a respiratory questionnaire was administered and spirometric data were collected on a large sample of Canadian children aged seven to 11 years in 1985 and 1986 (1). The present report uses this large sample from the Canadian Children's Health Survey (CCHS) for two purposes: first, to determine whether predicting lung function from a large population within a narrow age range offered any improvement over the standard prediction equations used in Canadian clinical laboratories, which were generated from much smaller samples of normal volunteers; and second, to examine the impact of weight on lung function for preteenaged Canadian children.

\section{SETTING}

The CCHS was undertaken to examine the effects of long range transported air pollution, principally ozone and sulphates, on the respiratory health of Canadians. Children in rural towns were studied because they would not be affected by a history of cigarette smoking or occupational exposure to pneumotoxins, and the towns were chosen with no point sources of industrial pollution. Five towns were selected in each of two areas for comparison. One area was of low pollution (Saskatchewan) and one of higher pollution (southwestern Ontario).

The methodology has been published in detail (1). Briefly, from a target population of all school children aged seven to 11 years in these 10 communities, questionnaires were completed for 4695 (96.1\%) of the children. For the purposes of the present analysis, asthmatics and children who smoked were excluded from this cohort. Non-Caucasian children were excluded due to differences in normal lung function and insufficient numbers for separate analysis (2). The exclusions were based on the modified American Thoracic Society (ATS) DLD-78C questionnaire responses (3). Children were considered to be asthmatic if parents answered affirmatively to both of the following questions: "Has a doctor ever said that this child had asthma?" and "Does he/she still have asthma?"

Spirometry was conducted in the schools between October 1985 and March 1986 by five trained technicians using a vertically displaced, computer-assisted, dry rolling seal spirometer (Gould Model 21E Gould Medical Products). Each child performed a minimum of five and a maximum of eight trials to obtain three acceptable manoeuvres. Criteria for acceptability were those recommended by the ATS Snowbird workshop (4). Criteria for test selection were maximum forced vital capacity (FVC) and forced expiratory volume in $1 \mathrm{~s}\left(\mathrm{FEV}_{1}\right)$ from a reproducible manoeuvre (ie, one in which another trial produced a score within $5.5 \%$ of the maximum value). All measurements were corrected for body temperature, ambient pressure and saturation with water vapour.

The results of the air pollution analysis showed no regional differences in symptomatology or chest illness. However, children living in southwestern Ontario exhibited statistically significant decrements in FVC an average of $1.7 \%$ lower than children residing in Saskatchewan. There were no regional differences in any of the flow parameters. This suggested the possibility that some of the observed east-west differences in lung function were due to body size rather than air pollution and provided the stimulus for conducting the portion of the present analysis, which looked at the effects of weight on FVC. 

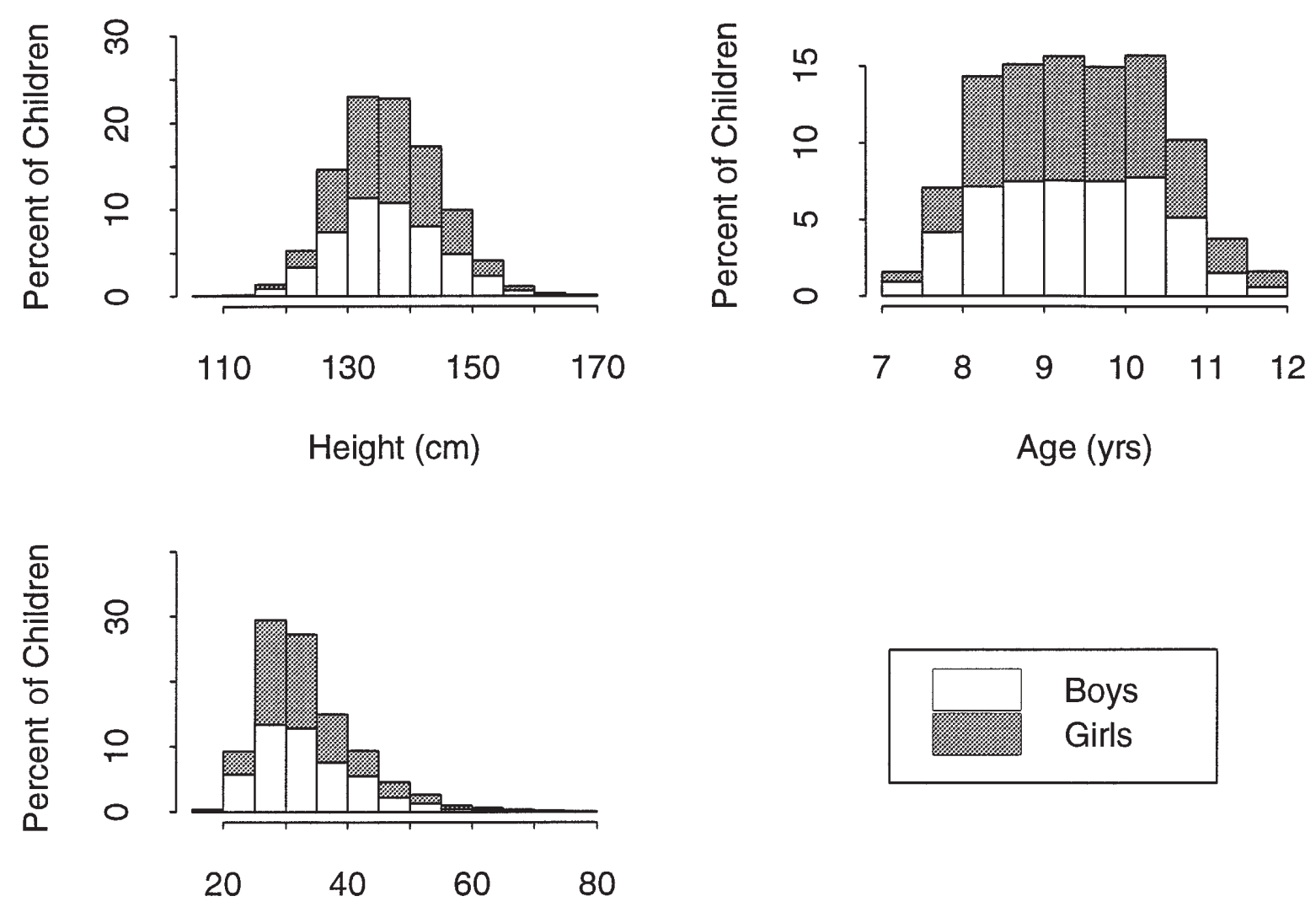

Weight $(\mathrm{kg})$

Figure 1) Frequency distributions of age, height and weight in boys and girls

\section{METHODS OF ANALYSIS}

A questionnaire survey was distributed to all pulmonary function laboratories in children's hospitals in Canada to inquire about prediction equations currently in clinical use for Caucasian children. The most frequently used equations were those of Polgar and Promadhat (5) and Weng and Levison (6). Polgar's subjects were American children (5) with data combined from several studies of small groups of volunteers' results, and Weng's were 139 healthy volunteers (6). A later unpublished extension of the latter study is used in several laboratories and is the equation used for comparison in the present study, ie,

$$
F V C=0.146^{(0.02 \cdot h e i g h t)}
$$

These prediction equations were compared with predictions generated from the cohort under study to determine whether a large sample's model varied from these predictions in either the mean predicted FVC or the lower limit of normal.

To compare predictions, the CCHS study data were divided into two separate groups by sex. Within each group a random sample of 500 test subjects was withdrawn and prediction curves of FVC based on height and age were regenerated for the remaining test subjects. The 500 withdrawn subjects in each group were then classified by each of the three prediction models as having abnormally low or normal lung function based on a 95\% lower-confidence interval (CCHS, Weng) or 2 SD below the mean (Polgar). The uncertainty coefficient statistic (7) was used to test the hypothesis of no association between prediction results according to CCHS and Weng and to CCHS and Polgar. A significant uncertainty coefficient would indicate that the two methods being compared classify children differently. It is particularly robust for situations in which there are large differences in marginal probabilities.

The effects of weight and body mass index (weight/ height ${ }^{2}$ ) on lung function were examined via multiple linear regression on models incorporating sex, age and height. Natural logarithms, and linear and quadratic terms for each variable were also examined in relation to FVC.

\section{RESULTS}

The 3142 healthy preteenaged children comprised 1575 boys and 1567 girls. Figure 1 provides the frequency distributions of age, height and weight within each sex. Whereas height appeared to be approximately normally distributed, weight had a skewed distribution with a longer tail for larger weights. Age was uniformly distributed for most of this very narrow age range with a few boys and girls who are younger 

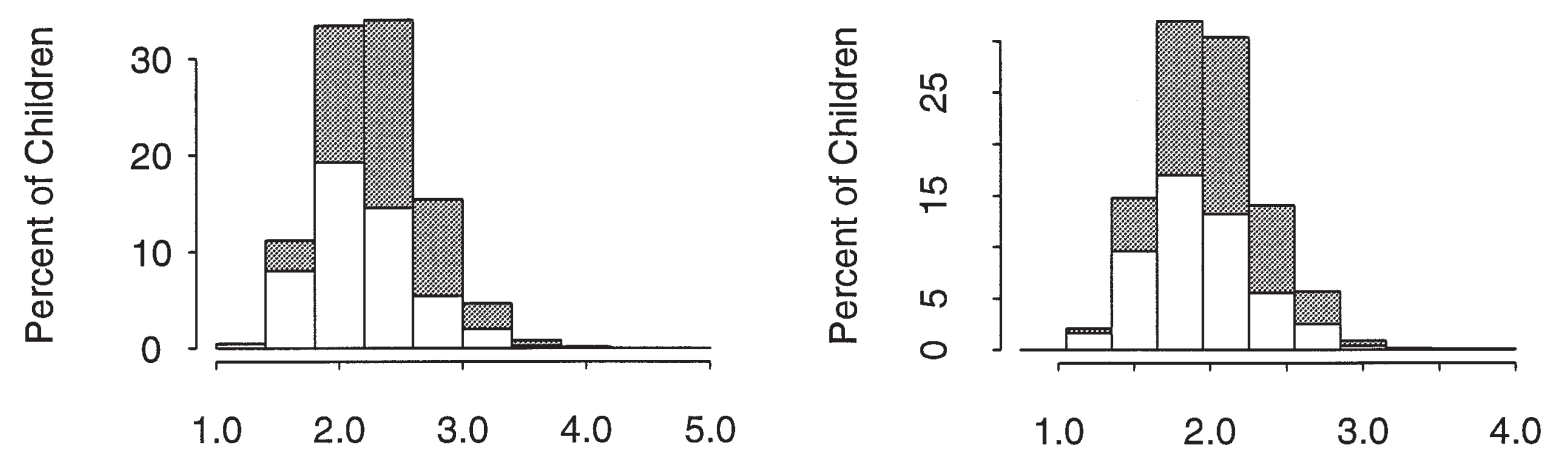

FVC (L)

\section{$\mathrm{FEV}_{1}(\mathrm{~L})$}

\section{Boys \\ Girls}

Figure 2) Frequency distribution of lung functions in boys and girls. FEV 1 Forced expiratory volume in 1 s; FVC Forced vital capacity

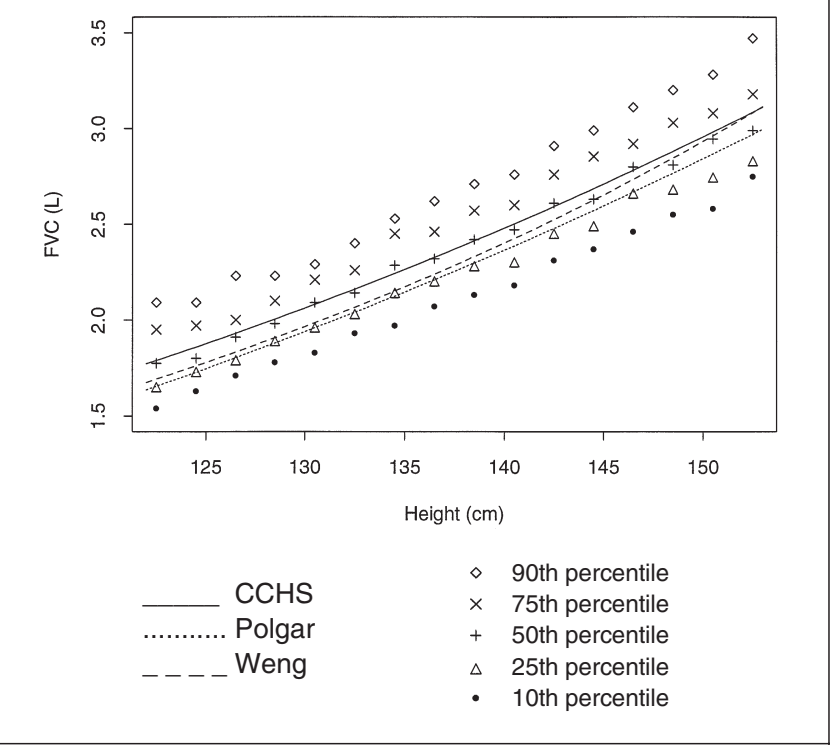

Figure 3) Comparison of population-based results for forced vital capacity $(F V C)$ in boys with standard mean prediciton curves. CCHS Canadian Children's Health Survey

and older. Seven years is about the youngest age at which children can be expected to perform pulmonary function manoeuvres reliably.

In Figure 2 the frequency distributions of $\mathrm{FVC}$ and $\mathrm{FEV}_{1}$ are shown to be nearly symmetrically distributed.

The FVC prediction equations are compared with the published prediction equations in current use in children's hospitals in Canada in Figures 3 and 4. The mean prediction curves for both Polgar and Weng clearly fall within the 95\% confidence intervals of the CCHS data generated from population-based samples in both boys and girls.

Table 1 shows the classification results of the 500 randomly selected subjects of each sex. The subtables present

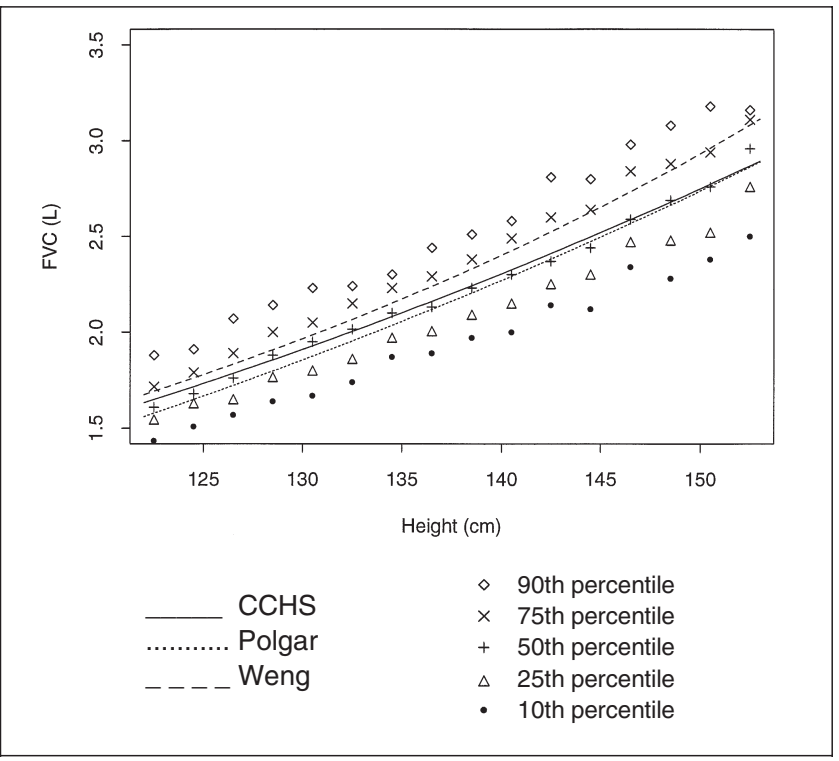

Figure 4) Comparison of population-based results for forced vital capacity $(F V C)$ in girls with standard mean prediction curves. CCHS Canadian Children's Health Survey

pairwise comparisons between CCHS and Polgar, and CCHS and Weng for determining abnormality where the cells of these tables contain the number of children that fell into each category. For example, the upper left hand corner of the first subtable (CCHS versus Polgar for girls) indicates that 458 girls were classified as normal by both models. Additionally, the Polgar model declared 32 girls to be below normal whom the CCHS model classified as normal.

The uncertainty coefficient statistic was not statistically significant in either comparison for either sex, indicating that the CCHS model does not classify children differently from the Polgar or Weng models.

In the regression analysis the significant independent pre- 


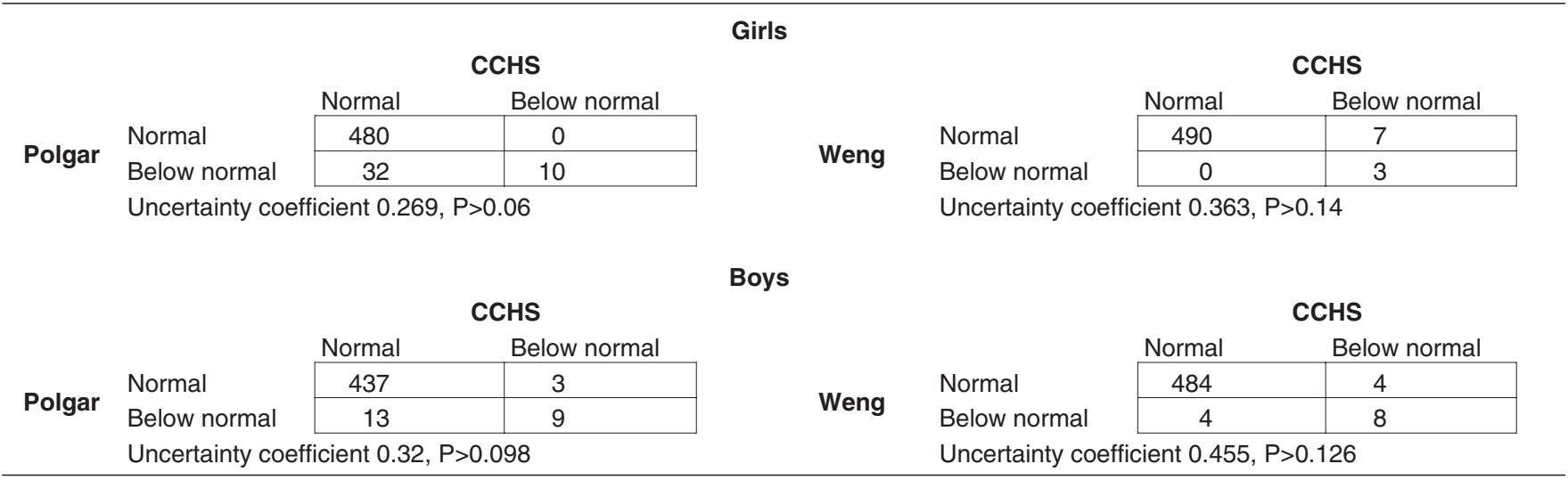

dictors of FVC are age, height, height ${ }^{2}$, and weight for boys, and height, height ${ }^{2}$, weight and weight ${ }^{2}$ for girls (Table 2). Applying the natural logarithm to each variable did not increase the overall $\mathrm{r}^{2}$ significantly. The improvement in $\mathrm{r}^{2}$ attributable to weight was approximately $2 \%$ of the variability; the overall model accounted for about $73 \%$ of the variability in the FVC.

Figures 5 and 6 illustrate the weight effect in FVC for boys and girls, respectively. Each line indicates the modelled relationship between FVC and weight for a given height. Along each line, or height isopleth, children of lower weights have lower FVC. The most obvious decrements occur in children weighing less than $30 \mathrm{~kg}$. The children from Saskatchewan were not different in weight from the children in Ontario and so this did not explain the differences in FVC between children from the two areas tested.

\section{DISCUSSION}

This study confirms the earlier report of Van Ganse in adults (8) that, when healthy nonasthmatic nonsmokers are studied, the recommended (9) use of a large population-based sample shows no difference over the prediction from a volunteer sample. Even though the values of Polgar and Weng are from much smaller samples and use different methodologies for testing, the results are sufficiently robust to be indistinguishable from a large population of seven- to 11-year-olds tested in 1987.

The effect of weight on pulmonary function has been previously described in adults by Schoenberg et al (10) as having two size-specific effects. First, in young adults, lung function increases with increasing weight; termed a 'muscularity effect'. Second, there is a decline in lung volume with further increases in weight, which is termed an 'obesity effect'.

In a smaller population of 314 young adults, McDonnell and Seal (11) also noted an association between lung volumes, particularly functional residual capacity, FVC, FEV 1 and body mass index. The variance accounted for by size was about $20 \%$ and was best described by a quadratic function that suggested an inverted ' $U$ '-shaped relationship (11).
TABLE 2

Multiple regression analysis results

\begin{tabular}{|c|c|c|c|c|}
\hline & \multicolumn{2}{|c|}{ Boys $(n=1575)$} & \multicolumn{2}{|c|}{ Girls (n=1567) } \\
\hline & $\begin{array}{c}\text { FVC } \\
\text { coefficient } \\
\text { (P) }\end{array}$ & $\begin{array}{c}\text { FEV }_{1} \\
\text { coefficient } \\
\text { (P) }\end{array}$ & $\begin{array}{c}\text { FVC } \\
\text { coefficient } \\
\text { (P) }\end{array}$ & $\begin{array}{c}\text { FEV }_{1} \\
\text { coefficient } \\
\text { (P) }\end{array}$ \\
\hline Intercept & $\begin{array}{c}4.051 \\
(0.004)\end{array}$ & $\begin{array}{l}1.934 \\
(0.13)\end{array}$ & $\begin{array}{c}2.414 \\
(0.047)\end{array}$ & $\begin{array}{c}2.388 \\
(0.037)\end{array}$ \\
\hline Age (years) & $\begin{array}{l}0.0138 \\
(0.04)\end{array}$ & $\begin{array}{l}0.021 \\
(0.0007)\end{array}$ & $\begin{array}{c}0.0072 \\
(0.307)\end{array}$ & $\begin{array}{l}0.0074 \\
(0.27)\end{array}$ \\
\hline Height (cm) & $\begin{array}{l}-0.069 \\
(0.0008)\end{array}$ & $\begin{array}{l}-0.0343 \\
(0.07)\end{array}$ & $\begin{array}{c}-0.0437 \\
(0.017)\end{array}$ & $\begin{array}{c}-0.0408 \\
(0.018)\end{array}$ \\
\hline Height $^{2}\left(\mathrm{~cm}^{2}\right)$ & $\begin{array}{c}0.00036 \\
(0.0001)\end{array}$ & $\begin{array}{c}0.00022 \\
(0.0013)\end{array}$ & $\begin{array}{c}0.00027 \\
(0.0001)\end{array}$ & $\begin{array}{c}0.00025 \\
(0.0001)\end{array}$ \\
\hline Weight (kg) & $\begin{array}{c}0.0377 \\
(0.0001)\end{array}$ & $\begin{array}{c}0.0177 \\
(0.0002)\end{array}$ & $\begin{array}{l}0.024 \\
(0.0001)\end{array}$ & $\begin{array}{c}0.0156 \\
(0.002)\end{array}$ \\
\hline Weight $^{2}\left(\mathrm{~kg}^{2}\right)$ & $\begin{array}{c}-0.0003 \\
(0.0001)\end{array}$ & $\begin{array}{c}-0.00013 \\
(0.0186)\end{array}$ & $\begin{array}{l}-0.00015 \\
(0.02)\end{array}$ & $\begin{array}{c}-0.00093 \\
(0.1328)\end{array}$ \\
\hline Model $r^{2}$ & 0.725 & 0.663 & 0.736 & 0.69 \\
\hline
\end{tabular}

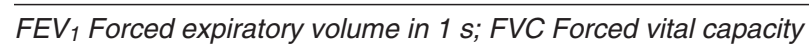

Again, there was an initial increase in lung volume with increasing size, which reached a plateau in the middle weight range. Subjects at the greatest weights demonstrated significantly lower lung volumes.

In children, Dockery et al (12) described a small effect of weight and age in a regression model where height, race, sex, and their interactions were regressed on the natural logarithms of FVC and FEV 1 . They felt, however that the more parsimonious three-variable model, which included sex, age, and height, would best describe growth. In 393 children aged nine to 17 years, Binder et al (13) has also shown a significant effect of weight.

Finally, in the second National Health and Nutrition Examination Survey conducted in the United States from 1976 to 1980 for nonsmoking healthy six- to 24-year-olds, the body mass index was a significant factor in regression models for FVC and flow rates after adjustment for height, race and sex. However, when presenting percentile growth curves, these authors chose to include only height, race and sex (14). 


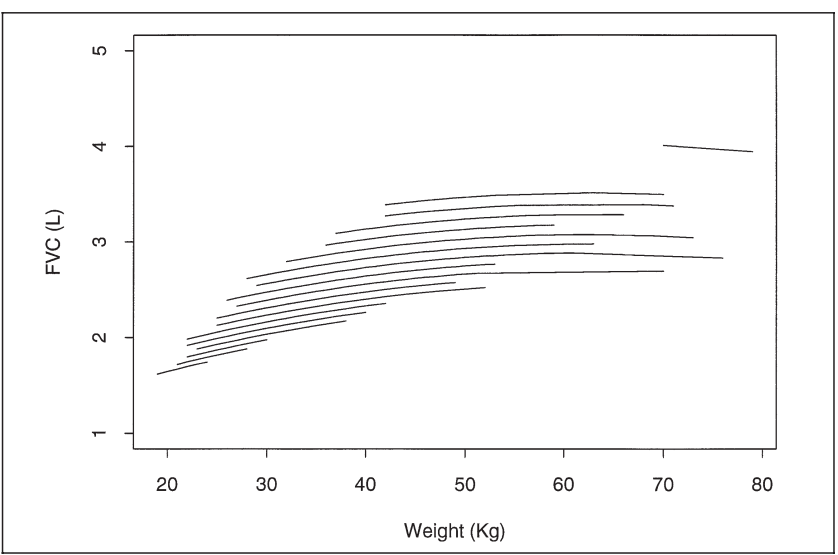

Figure 5) Effect of weight on forced vital capacity (FVC) in boys. Each line represents a height isopleth

In fact, most authors and standardization committees $(3,15)$ have agreed that the magnitude of the weight effect in both children and adults is insufficient to justify its inclusion in prediction equations used clinically. On the other hand, the magnitude of the variance attributable to weight (or any other formulation of body size, muscularity or fitness such as surface area or body mass index) has been seen to be similar in order of magnitude to the effect of potential pulmonary toxins such as air pollutants and passive or maternal smoking.

This analysis indicates a third size-specific effect of weight: the negative effect of weight in the smallest children. Whereas the attainment of muscularity has been shown to exert a positive weight effect in the young adult (2), here the lower the weight, the lower the FVC for height in Canadian

\section{REFERENCES}

1. Stern B, Raizenne M, Burnett R, Jones L, Kearney J, Franklin C. Air pollution and childhood respiratory health exposure to sulfate and ozone in 10 Canadian rural communities. Environ Res 1994;66:125-42.

2. Rossiter CE, Weill H. Ethnic differences in lung function: evidence for proportional differences. Int J Epidemiol 1974;3:55-61.

3. B Ferris, ed. Epidemiology Standardization Project. Am Rev Resir Dis 1978;118(Pt 2):11-59.

4. ATS Statement - Snowbird Workshop on Standardization of Spirometry. Am Rev Respir Dis 1978;119:831.

5. Polgar G, Promadhat V. Pulmonary Function Testing in Children. Techniques and Standards. Philadelphia: WB Saunders Co, 1971.

6. Weng TR, Levison H. Standards of pulmonary function in children. Am Rev Respir Dis 1969;99:879-94.

7. Goodman LA, Kruskal WH. Measures of association for cross-classification IV. J Am Statistical Assoc 1972;67:415-21.

8. Van Ganse W, Billiet L, Ferris BG. Medical criteria for the selection of normal subjects. In: Arcangeli P, Cotes JC, Cournand A, et al, eds. Normal Values for Respiratory Function in Man. Alghero: Panminerva Medica, 1970:15-27.

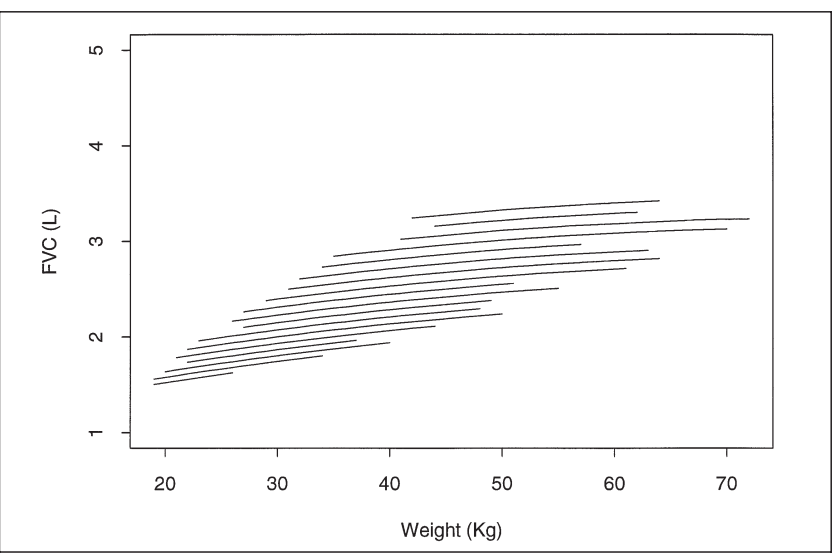

Figure 6) Effect of weight on forced vital capacity (FVC) in girls. Each line represents a height isopleth

preteenaged boys and girls. This is presumed to indicate an absence of muscularity rather than of cooperation or coordination since the latter would be expected to increase with age but not with height. The lower the pressure generated, the lower the FVC, as has been shown in other Canadian children, teenagers and young adults (16). The magnitude of the weight effect is small and probably can be seen only when large numbers of children within a narrow age range can be analyzed, as in CCHS. However, in young children weight may be an important factor in the examination of effects on lung function of such factors as environmental smoking or air pollution exposure, which are expected to be equally small but most likely identifiable only in preteenaged children before active smoking becomes a major confounder.

9. Lung function testing: selection of reference values and interpretative strategies. ATS position paper. Am Rev Respir Dis 1991;144:1202-18.

10. Schoenberg JB, Beck GJ, Bouhuys A. Growth and decay of pulmonary function in healthy blacks and whites. Respir Physiol 1978;33:367-93.

11. McDonnell WF, Seal E Jr. Relationships between lung function and physical characteristics in young adult black and white males and females. Eur Respir J 1991;4:279-89.

12. Dockery DS, Berkey JH, Speizer FE, Ferris BG. Distribution of forced vital capacity and forced expiratory volume in one second in children 6 to 11 years of age. Am Rev Respir Dis 1983;128:405-12.

13. Binder RE, Mitchell CA, Schoenberg J, Bouheys A. Lung function among black and white children. Am Rev Respir Dis 1976;114:955-9.

14. Schwartz JD, Katz SA, Fegley RW, Tockman MS. Analysis of spirometric data from a national sample of healthy 6 to 24 year olds (NHANES). Am Rev Respir Dis 1988;138:1405-14.

15. Quanjer H, Dalhuijsen A, Van Zomeren BC. Summary equations of reference values. Bull Eur Physiopathol Respir 1983;19(Suppl 5):45-51.

16. Leech JA, Ghezzo H, Stevens D, Becklake MR. Respiratory pressures and function in young adults. Am Rev Respir Dis 1983;128:17-23. 


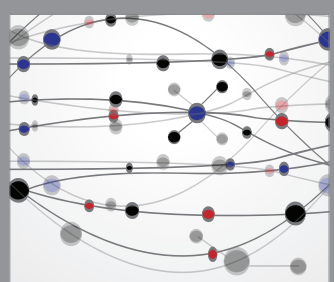

The Scientific World Journal
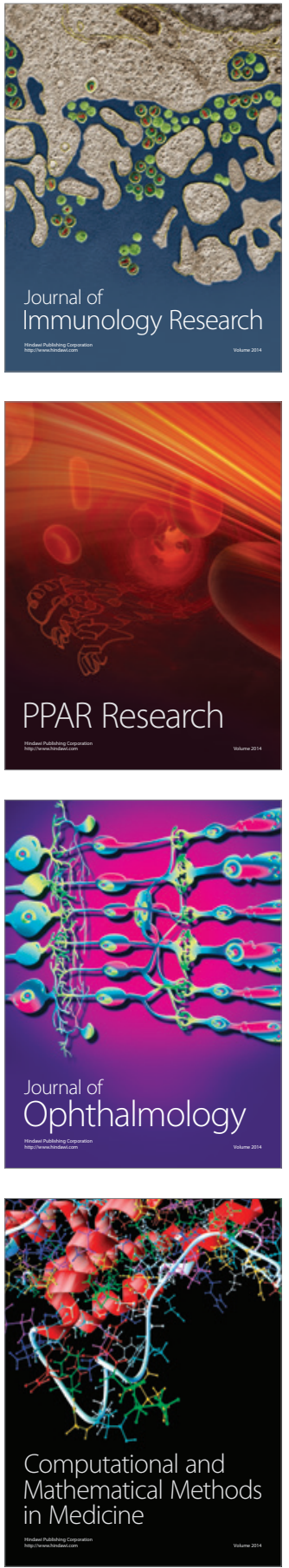

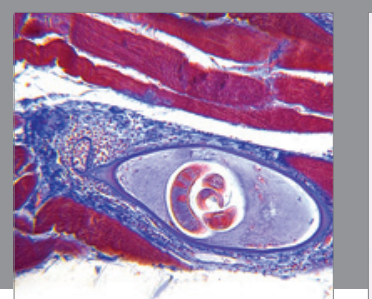

Gastroenterology Research and Practice

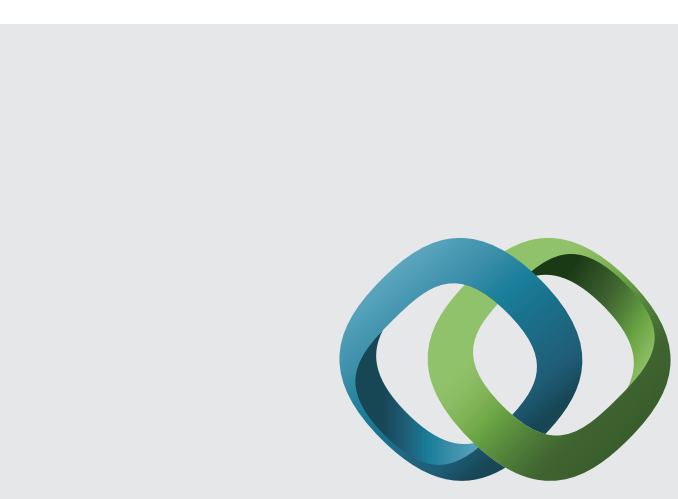

\section{Hindawi}

Submit your manuscripts at

http://www.hindawi.com
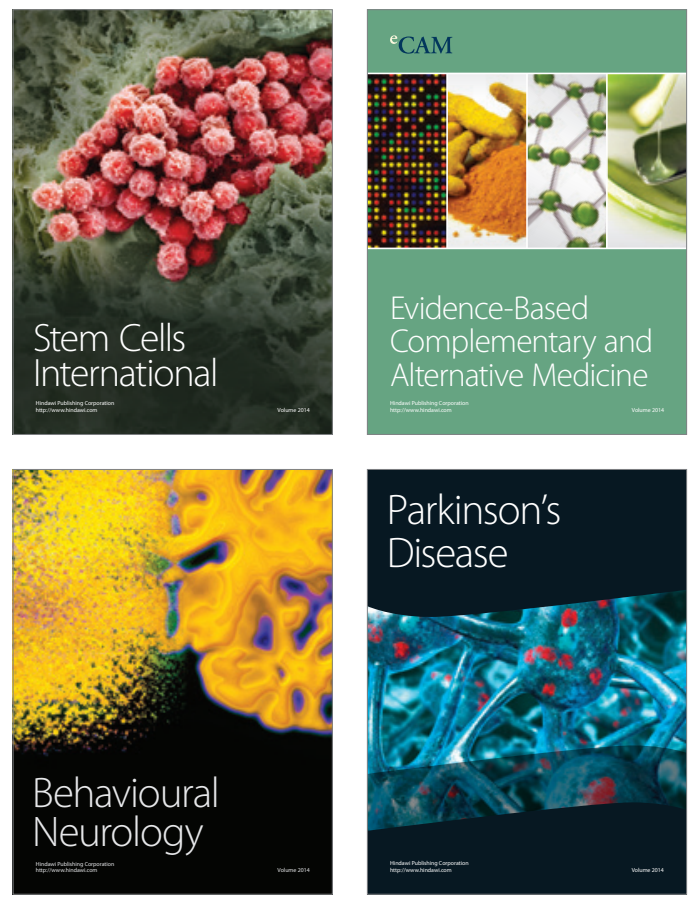
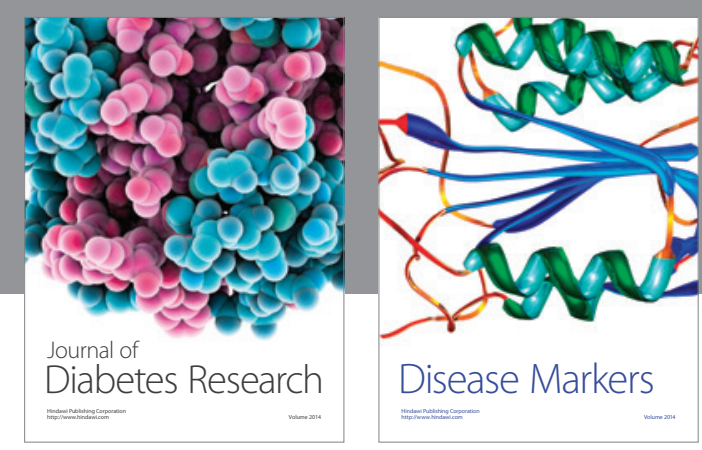

Disease Markers
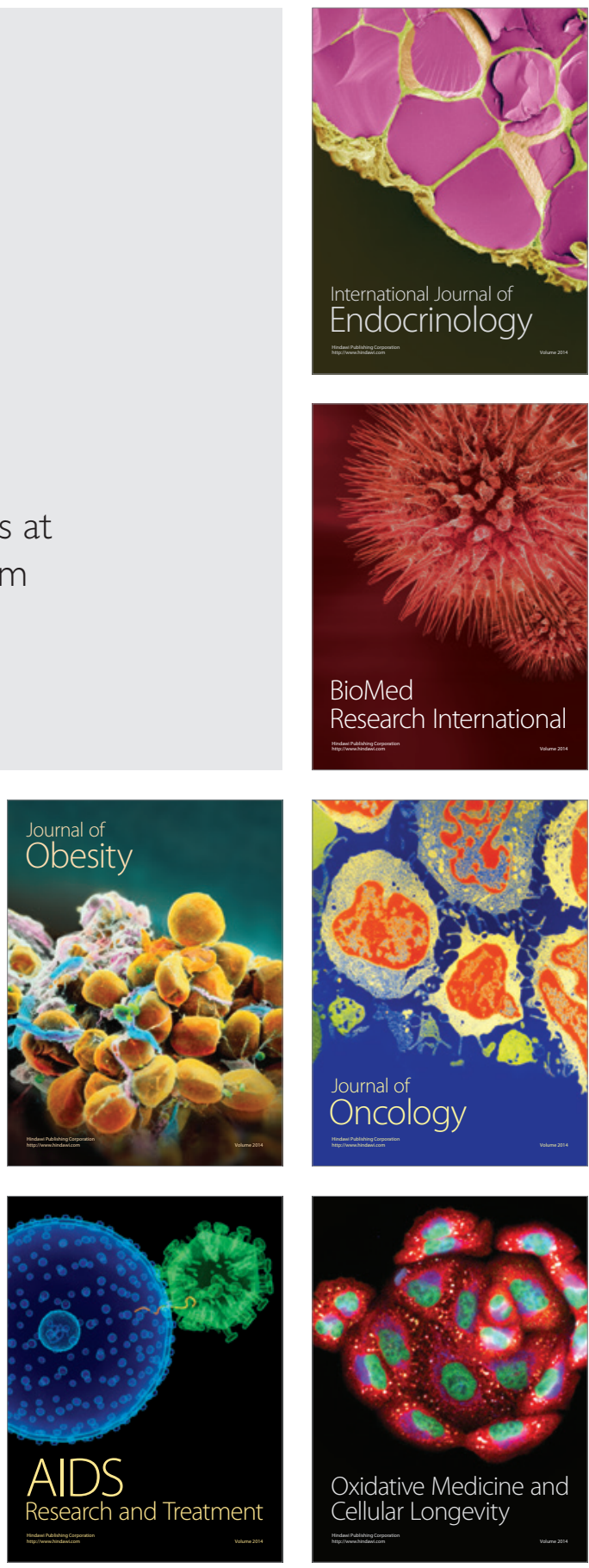